\title{
Routine Investigations in the Antenatal Booking Visit: An Epidemiological Survey
}

\author{
REEM S. BEDEIR, M.Sc.; BOTHINA A. GHAZY, M.D. and ABD E-LFATTAH MOHAMMED, M.D. \\ The Department of Obstetrics \& Gynecology, Faulty of Medicine for Girls, Al-Azhar University
}

\begin{abstract}
Background: The antenatal care investigations is very important to determine the antenatal care problems, manage these problems and decrease the maternal morbidity and mortality.
\end{abstract}

Aim of Study: Is to identify the medical pattern in the egyptian pregnant women from Kafr El-Sheikh according to the results of the booking test.

Patients and Methods: Cross sectional study was done over 1260 pregnant women from 2015 to 2017 from the outpatient clinic of Obstetrics and Gynecology in Kafr ElSheikh General Hospital, out of them 260 pregnant women stepped out of the study, all the pregnant women was asked to do the following antenatal care laboratory investigations, complete blood count, random blood sugar, Rh typing, cytomegalovirus (CMV) IgG antibodies, hepatitis B virus surface antigen, hepatitis $\mathrm{C}$ virus antibodies, high vaginal swap for bacterial vaginosis, urine analysis, all the data gathered for each woman in a file with her name for the statistical analysis.

Results: Percentage of anemia was $47.1 \%$ with negative significant correlation with age, percentage of DM was $8.1 \%$, percentage of Rh negative was $12.6 \%$, percentage of CMV IgG was $85.7 \%$, percentage of $\mathrm{HBV}$ was $2.4 \%$, percentage of $\mathrm{HCV}$ was $7.9 \%$ with positive significant correlation with history of previous CS, percentage of bacterial vaginosis was $27 \%$ and percentage of UTI was $62 \%$.

Conclusion: A lot of women in Kafr El-Sheikh do not know the importance of the antenatal investigations and the control of the antenatal problems.

Recommendations: There is need for give more concern about routine antenatal care investigations and it's importance and routine screening for anemia, DM, Rh, CMV, HBV, HCV, $\mathrm{BV}$ and UTI.

Key Words: Antenatal care-Anemia-Diabetes mellitus Rh negative - Cytomegalovirus IgG - Hepatitis $B$ virus - Hepatitis $C$ virus - Bacterial vaginosis - Urinary tract infection.

Correspondence to: Dr. Reem S. Bedeir, The Department of Obstetrics \& Gynecology, Faulty of Medicine for Girls, Al-Azhar University

\section{Introduction}

ANTENATAL Care (ANC) means "care before birth", and includes education, counseling, screening and treatment to monitor and to promote the well-being of the mother and fetus. The current challenge is to find out which type of care and in what quantity is considered sufficient to ensure good quality of care for low-risk pregnant women [1].

The recommended content of antenatal care according to (NICE, 2007):

A- Antenatal education.

B- Provision and organization of care.

C- Lifestyle considerations.

D- Management of common symptoms of pregnancy.

E- Clinical examination of pregnant women.

F- Screening for hematological conditions.

G- Screening for infections.

$\mathrm{H}-$ Screening for clinical conditions.

I- Fetal growth and wellbeing.

J- Screening for fetal anomalies.

K- Management of specific clinical conditions [2]

Results from a blood type test can show if you have the $\mathrm{Rh}$ factor. The $\mathrm{Rh}$ factor is a protein that can be present on the surface of red blood cells. Most people have the Rh factor-they are Rh positive. Others do not have the $\mathrm{Rh}$ factor-they are $\mathrm{Rh}$ negative. If your fetus is $\mathrm{Rh}$ positive and you are $\mathrm{Rh}$ negative, your body can make antibodies against the $\mathrm{Rh}$ factor. In a future pregnancy, these antibodies can damage the fetus's red blood cells [3]

All pregnant women should undergo blood grouping determination. Anti-D (formerly Rh), given to pregnant women within 72 hours after 
childbirth, reduces the risk of Rh D alloimmunization in Rh negative women who have given birth to an Rh-positive infant. However evidence of the optimal dose is limited. Higher doses (up to 200 micrograms) have been shown to be more effective than lower doses (up to 50 micrograms) in preventing $\mathrm{Rh} \mathrm{D}$ alloimmunization in a subsequent pregnancy [3].

Anemia is the most common nutritional deficiency disorder in the world. WHO has estimated that prevalence of anemia in developed and developing countries in women go through a variety of physiological changes during pregnancy. Changes in the blood circulatory system are particularly notable, permitting normal fetal growth. Even in normal pregnant women, the hemoglobin concentration decreases with dilution according to the increase in the volume of circulating blood. Since iron and folic acid in amounts necessary to the fetus are preferentially transported to the fetus, the mother is likely to develop iron deficiency anemia and folic acid deficiency anemia. About $20 \%$ of pregnant women suffer anemia, and most of the cases are iron deficiency, folic acid deficiency, or both [4].

Urinary Tract Infections (UTIs) are one of the most frequent complications during pregnancy . Traditionally Urinary Tract Infection (UTI) is classified as either involving the lower urinary tract (acute cystitis) or the upper urinary tract (acute pyelonephritis). A predisposing factor or precursor to UTI is bacteriuria. Smooth muscle relaxation results in decreased peristalsis of the ureters, increased bladder capacity and urinary stasis. Differences in urine $\mathrm{pH}$ and osmolality and pregnancy-induced glycosuria and aminoaciduria may facilitate bacterial growth. Urinary tract infections in pregnancy are classified as either asymptomatic or symptomatic. Asymptomatic bacteriuria is defined as the presence of significant bacteriuria without the symptoms of an acute urinary tract infection. Symptomatic urinary tract infections are divided into lower tract (acute cystitis) or upper tract (acute pyelonephritis) infections. Cystitis is defined as significant bacteriuria with associated bladder mucosal invasion, whereas pyelonephritis is defined as significant bacteriuria with associated inflammation of the renal parenchyma, calices and pelvis [5].

Hepatitis B and hepatitis C viruses infect the liver. Pregnant women who are infected with hepatitis B or hepatitis C virus can pass the virus to their babies. All pregnant women are tested for hepatitis B virus infection. If you have risk factors, you also may be tested for the hepatitis $C$ virus. Mother-to-child transmission of the Hepatitis B (HB) virus is preventable in $95 \%$ of cases through administration of vaccine and immunoglobulin to the baby at birth. To prevent mother-to-child transmission, all pregnant women who are carriers of Hepatitis B (HB) virus need to be identified. Blood sample screening is the accepted standard for antenatal screening for Hepatitis B (HB) virus [6]

Newly infected people with Hepatitis C Virus (HCV) are generally asymptomatic, but they may present with mild clinical illness. After exposure HCV RNA is detectable within 1-3 weeks, with the typical time from exposure to Hepatitis C Virus (HCV) antibody seroconversion (anti-HCV) occurring in 8-9 weeks. Chronic Hepatitis C Virus (HCV) infection develops in 70-80\% of people infected with Hepatitis C Virus (HCV), and 60-70\% of these chronically infected people will exhibit signs of active liver disease. Because most infected people are unaware of their status due to lack of clinical symptoms they can provide risk to others for Hepatitis C Virus (HCV) transmission. People with chronic Hepatitis C Virus (HCV) generally remain asymptomatic for 20-30 years [7]. 20\% will develop cirrhosis, and 1-6\% will develop hepatocellular carcinoma. The remaining $35 \%$ with chronic Hepatitis C Virus (HCV) may die from other morbidities, develop slowly advancing liver disease, or they may continue with persistent Hepatitis C Virus (HCV) infection and stable liver disease [8]

Congenital cytomegalovirus (CMV) infection is the leading cause of infectious congenital defects and disabilities. Its transmission can occur in primary and non-primary infections; however the transmission rate is considerably higher in primary infections. Cytomegalovirus (CMV) is widely distributed among humans. As other viruses of the Herpes viridae family, it causes a primary infection and then remains latent in the body. Despite causing a usually harmless primary infection, cytomegalovirus (CMV) can be life-threatening for immunocompromised patients and can cause serious fetal damages. Hence, infection in pregnant women assumes high importance [9].

Bacterial vaginosis is a syndrome that can be diagnosed both clinically and microbiologically. Diagnostic criteria are the same for pregnant and non-pregnant women. Amsel et al., published clinical diagnostic criteria in 1983, and these are still in use today. The clinical diagnosis of bacterial vaginosis is made if three of the four following signs are present [10]. 
- An adherent and homogenous vaginal discharge.

- Vaginal $\mathrm{pH}$ greater than 4.5.

- Detection of clue cells (vaginal epithelial cells with such a heavy coating of bacteria that the peripheral borders are obscured) on saline wet mount.

- An amine odour after the addition of potassium hydroxide (positive whiff test).

Gram stain of vaginal fluid is the most widely used and evaluated diagnostic method for bacterial vaginosis. To perform a gram stain, vaginal discharge is collected on a glass slide, allowed to air dry, stained in the laboratory, and examined under oil immersion for the presence of bacteria. Most laboratories use an objective diagnostic scheme that quantifies the number of Lactobacillus morphotypes and pathogenic bacteria, resulting in a score that is used to determine whether the infection is present [11].

Untreated gestational diabetes (GDM, an abnormal, pregnancy-related glucose level in the mother) can lead to serious problems for mother and fetus. At present, Gestational Diabetes Mellitus (GDM) screening appears to be hampered by the lack of a clear definition of risk, and agreed diagnostic criteria. Risk factors for Gestational Diabetes Mellitus (GDM) are neither selective nor specific enough, and are therefore useless. However, there is good evidence showing that interventions and treatments, like dietary counseling, blood glucose monitoring, and insulin (if appropriate), lead to improved outcomes for mother and fetus. The best test at present is probably the glucose challenge test, preferably combined with a fasting plasma glucose [12].

\section{Patients and Methods}

A cross-sectional study was held in the period from April 2015 to 2017 on 1260 pregnant women who attended the outpatient clinic of Obstetrics and Gynecology in Kafr El-Sheikh General Hospital at their booking antenatal care visit, 260 pregnant women were enrolled out of the study.

\section{All patients were subjected to the following:}

- Verbal consent.

- Detailed clinical history.

Personal history, obstetric history, present history, past history, surgical history, general examination.
All the pregnant women was asked to do the following antenatal care laboratory investigations:

- Complete blood count.

- Random blood sugar.

- Rh typing.

- Cytomegalovirus (CMV) IgG antibodies.

- Hepatitis B virus surface antigen.

- Hepatitis $\mathrm{C}$ virus antibodies.

- High vaginal swap for bacterial vaginosis

- Urine analysis.

All the data gathered for each women in a file with her name for the statistical analysis.

\section{Results}

This study was performed over 1260 pregnant women of whom 260 women refused to be included among this study, so this study was done on 1000 pregnant women.

Table (1): Number and percentage of anemia among studied groups.

\begin{tabular}{lll}
\hline Anemia & No. & $\%$ \\
\hline Positive & 471 & 47.1 \\
Negative & 529 & 52.9 \\
\hline Total & 1000 & 100 \\
\hline
\end{tabular}

Table (1) is showing number and percentage of anemia among studied groups as, $471(47.1 \%)$ had anemia while $529(52.9 \%)$ had normal $\mathrm{Hb}$ level.

Table (2): Correlation between anemia and age, occupation, parity and labor.

\begin{tabular}{cc}
\hline Variable & Anemia \\
\hline Age: & \\
$r$ & -0.081 \\
$p$ & $0.010^{*}$ \\
Occupation: & \\
$r$ & -0.014 \\
$p$ & 0.664 \\
Parity: & \\
$r$ & 0.059 \\
$p$ & 0.062 \\
Labor: & \\
$r$ & 0.080 \\
$p$ & $0.011^{*}$ \\
\hline
\end{tabular}

Table (2) shows that there was negative significant correlation between anemia and age while there was positive correlation between anemia and type of labor. 
Table (3): Number and percentage of diabetes mellitus among studied groups.

\begin{tabular}{lll}
\hline Diabetes mellitus & No. & $\%$ \\
\hline Positive & 81 & 8.1 \\
Negative & 919 & 91.9 \\
\hline Total & 1000 & 100 \\
\hline
\end{tabular}

Table (3) is showing number and percentage of diabetes mellitus among studied groups as, 81 (8.1\%) had diabetes mellitus while 919 (91.9\%) were normal pregnancy.

Table (4): Number and percentage of Rhesus gene (Rh) among studied groups.

\begin{tabular}{llc}
\hline Rh & No. & $\%$ \\
\hline Positive & 874 & 87.4 \\
Negative & 126 & 12.6 \\
\hline Total & 1000 & 100 \\
\hline
\end{tabular}

Table (4) is showing number and percentage of Rhesus gene (Rh) among studied groups as, 874 $(87.4 \%)$ out of the patients were Rh positive while $126(12.6 \%)$ out of the patients were Rh negative.

Table (5): Number and percentage of cytomegalovirus (CMV IgG) among studied groups.

\begin{tabular}{lcc}
\hline CMV & No. & $\%$ \\
\hline Positive & 857 & 85.7 \\
Negative & 143 & 14.3 \\
\hline Total & 1000 & 100 \\
\hline
\end{tabular}

Table (5) is showing number and percentage of cytomegalovirus (CMV IgG) among studied groups as, $857(85.7 \%)$ out of the patients were positive for CMV IgG while $143(14.3 \%)$ out of the patients were negative for CMV IgG.

Table (6): Number and percentage of Hepatitis B Virus (HBV) among studied groups.

\begin{tabular}{lll}
\hline HBV & No. & $\%$ \\
\hline Positive & 24 & 2.4 \\
Negative & 976 & 97.6 \\
\hline Total & 1000 & 100 \\
\hline
\end{tabular}

Table (6) is showing number and percentage of Hepatitis B Virus (HBV) among studied groups as, $24(2.4 \%)$ out of the patients were positive HBV while 976 (97.6\%) out of the patients were negative HBV.
Table (7): Number and percentage of Hepatitis C Virus (HCV) among studied groups.

\begin{tabular}{lll}
\hline HCV & No. & $\%$ \\
\hline Positive & 79 & 7.9 \\
Negative & 921 & 92.1 \\
\hline Total & 1000 & 100 \\
\hline
\end{tabular}

Table (7) is showing number and percentage of Hepatitis C Virus (HCV) among studied groups as, $79(7.9 \%)$ out of the patients were positive HCV while $921(92.1 \%)$ out of the patients were negative $\mathrm{HCV}$.

Table (8): Correlation between Hepatitis C Virus (HCV) age, occupation, parity and labor.

\begin{tabular}{cc}
\hline Variable & HCV \\
\hline Age: & \\
$r$ & 0.056 \\
$p$ & 0.076 \\
Occupation: & \\
$r$ & 0.015 \\
$p$ & 0.634 \\
Parity: & \\
$r$ & 0.354 \\
$p$ & $0.000^{*}$ \\
Labor: & \\
$r$ & 0.137 \\
$p$ & 0.000 \\
\hline
\end{tabular}

Table (8) show that there was positive significant correlation between Hepatitis C Virus (HCV) and parity and type of labor.

Table (9): Number and percentage of bacterial vaginosis among studied groups.

\begin{tabular}{lll}
\hline Bacterial Vaginosis & No. & $\%$ \\
\hline Positive & 270 & 27 \\
Negative & 730 & 73 \\
\hline Total & 1000 & 100 \\
\hline
\end{tabular}

Table (9) is showing number and percentage of bacterial vaginosis among studied groups as, $270(27 \%)$ out of the patients were positive for bacterial vaginosis while $730(73 \%)$ out of the patients were negative foe bacterial vaginosis.

Table (10): Number and percentage of Urinary Tract Infection (UTI) among studied groups.

\begin{tabular}{lll}
\hline Urinary tract infection (UTI) & No. & $\%$ \\
\hline Positive & 620 & 62 \\
Negative & 380 & 38 \\
\hline Total & 1000 & 100 \\
\hline
\end{tabular}


Table (10) is showing number and percentage of Urinary Tract Infection (UTI) among studied groups as, $620(62 \%)$ out of the patients had positive pus cells while 380 (38\%) out of the patients had negative pus cells.

\section{Discussion}

In 2015, an estimated 303000 women died from pregnancy-related causes and 2.6 million babies were stillborn, half occurring during the third trimester. Many of these adverse outcomes can be prevented by quality healthcare during pregnancy and childbirth. Within the continuum of care, antenatal care (ANC) provides a platform for critical healthcare functions including health promotion, prevention, screening and diagnosis of diseases. Implementing timely and appropriate evidence-based practices during antenatal care (ANC) can improve maternal and fetal health. Furthermore, it is an opportunity to communicate with and support women, families and communities at this very pivotal time in the course of their lives [13].

The percentage of anemia in Kafr El-Sheikh is $47.1 \%$, it was reported before in other studies in Egypt to be $62.2 \%$ [14], 52.5\% [15] and it is also reported in 2014 by the world bank health nutrition and population statistics that it declines in Egypt from $35.9 \%$ to $30.4 \%$. This decline in percentage of anemia may be due to the use of iron and folic acid supplement and strengthened health educations given at health centers and also due to the time difference [15]

In our study there was negative significant correlation between anemia and age of pregnant women as anemia is $37.9 \%$ among women aged 20-30 years as it is the main reproductive age so repeated pregnancies with depletion of iron stores through short period of time, repeated deliveries with repeated blood loss and a lot of duties making pregnant women neglect eating properly so among our study most of pregnant women belong to this group of age and that is similar to other studies as [16] which revealed that anemia found to be more prevalent in women aged between 21-30 at 39.1\% as compared to $29.8 \%$ in the $15-20$ year age group and $29.9 \%$ in the above thirty age group, and [17] which revealed that anemia found to be more prevalent in women aged between 20-29 at 239 pregnant women as compared to 42 in the under twenty age group and 147 in the 30-34 age group.

There was significant correlation between anemia and type of labor as it was found to be more with caesarean section more than normal labor as shown in other study [18] which found that anemia is more with the history of surgical operations, also it is because blood loss after caesarean section is more than blood loss after normal vaginal delivery as shown in other study [19] which found blood loss after caesarean section is about $1200-1500 \mathrm{ml}$ while with normal vaginal delivery is about $500 \mathrm{ml}$.

In our study, 81 case have diabetes with pregnancy and percentage was $8.1 \%$. Diabetes with pregnancy (DM) was reported in another study in Egypt as it was 8\% [20].

The percentage of diabetes with pregnancy in our study is intermediate according to the results published by the national institution of health as it reported that diabetes with pregnancy percentage ranges from $4.9 \%$ to $12.8 \%$ [21], and the percentage of diabetes with pregnancy in our study was exactly similar to a study have been done in china which was $8.1 \%$ [22]

In our study, Rhesus gene positivity percentage among pregnant women was $87.4 \%$ while Rhesus gene negativity percentage was $12.6 \%$. It is in the same range of other studies as it was in Nigeria $7.1 \%$ [23], other study in Nigeria 9.5 [24], in Ethiopia $8.8 \%$ [25].

In current study, the percentage of cytomegalovirus immunoglobulin class $\mathrm{G}$ (CMV $\mathrm{IgG}$ ) was $85.7 \%$, it was reported before in Egypt that cytomegalovirus immunoglobulin class $\mathrm{G}$ (CMV $\mathrm{IgG}$ ) among pregnant women was $97 \%$ [26] and $75.1 \%$ [27] and it have been reported that, Africa have one of the highest prevalence of CMV as in Egypt, CMV seroprevalence among pregnant women was $96 \%$ [28]. This high percentage may be attributed to the low socioeconomic status, poor hygienic practices, lack of education about washing hands, which might play important roles in increasing the rate of cytomegalovirus (CMV) infection it is similar to other studies in other countries such as in Brazil was 84\% [29].

In our study, the percentage of Hepatitis B Virus (HBV) infection among the pregnant women from Kafr El-Sheikh was 2.4\%. This percentage was in the same range of other study in Menoufia as it was $2.3 \%$ [30], it was lower than previous studies in Assuit which was reported in 1993 to be $14.7 \%$ [31] and in 2010 it was $4 \%$ [32], while in cairo the percentage of hepatitis $B$ virus infection among pregnant women was lower than all of that as it was reported in 2013 to be $1.7 \%$ [33] and this may be due to the more awareness and education of the people, the higher socioeconomic conditions 
in cairo, the more hygienic environment and lower bad behavioral and cultural practices [33].

In our study, the percentage of Hepatitis C Virus (HCV) infection among pregnant women in Kafr El-Sheikh General Hospital was 7.9\% which was similar to other studies in Egypt as it was reported to be $8.6 \%$ in 2010 [34], between 5-15\% in 2013 [35] and $6.1 \%$ in 2014 [36]. It was higher than other study as it was $1.46 \%$ in Upper Egypt in 2016 [37]. It was lower than other study as in El-Behira, Egypt was $10.4 \%$ in 2015 [38]

In the current study it is reported that bacterial vaginosis among pregnant women in Kafr ElSheikh General Hospital was $27 \%$. It was reported globally in Gideon book to be 33.3\% in Egypt [39] This high percentage of bacterial vaginosis among pregnant women in Kafr El-Sheikh may be due to the low socioeconomic level, low hygienic level, and the unawareness of the women about the abnormal vaginal secretions and proper personal hygiene as wiping from front to back [40].

The percentage of Urinary Tract Infection (UTI) among pregnant women in our study was $62 \%$. It was reported before in Egypt to be 32\% [41], 31.3\% and within the range of $22-35 \%$ [42], this high percentage was explained to be due to the physiological changes associated with pregnancy, such as the relaxation of the ureter under the effect of hormones, increase the urinary output, resulting in urinary stasis [43]

\section{Conclusion and Recommendations:}

There is need for give more concern about routine antenatal care investigations and it's importance and routine screening for anemia, DM, Rh, CMV, HBV, HCV, BV and UTI.

\section{References}

1- BEREKET TESHOME: "The Challenges of Implementing Reproductive Health and related programs: The Case of Mokonisa Rural Keble, Wonago woreda, Gedeo zone, SNNPRs." PhD diss., AAU, 5: Doi: 10.1186/1756-0500, 2014.

2- NICE (The National Institution for Health and Care Excellence): Antenatal care: Routine care for the healthy pregnant woman, (1) 3, 2007.

3- KOSCHORKE A., EGBOR M. and BHIDE A.: Haematological Disorders and Red-Cell Alloimmunization in Pregnancy. Arias' Practical Guide to High-Risk Pregnancy and Delivery: A South Asian Perspective, p. 233, 2015.

4- Di RENZO G.C., SPANO F., GIARDINA I., BRILLO E., CLERICI G. and ROURA L.C.: Iron deficiency anemia in pregnancy. Women's Health, 11 (6): pp. 891-900. Article ID: 12546, 2015.
5- WAMALWA P., OMOLO J. and MAKOKHA A.: Prevalence and risk factors for urinary tract infections among pregnant women. Prime J. Soc. Sci., 2: 524-31, 2013.

6- SAAD SAIF ELESLAM and IBRAHIM HASSAN: Serodiagnosis of Hepatitis B Virus Surface Antigen among Pregnant Women in Khartoum State. Diss. Sudan University of Science \& Technology. 22-35; DOI: 10.2154/8546, 2016.

7- Centers for Disease Control and Prevention: Sexually transmitted diseases treatment guidelines, 2010. Annals of Emergency Medicine, 58 (1): 67-8, 2011.

8- JAIN SANGEETA, NIMA GOHARKHAY, GEORGE SAADE, GARY D. HANKINS, and GARLAND D. ANDERSON: "Hepatitis $C$ in pregnancy." American journal of perinatology, 24, (04): 251-6, DOI.10/2154/CDC/ 6548.251, 2007.

9- BIALAS K.M., SWAMY G.K. and PERMAR S.R.: Perinatal cytomegalovirus and varicella zoster virus infections: Epidemiology, prevention, and treatment. Clinics in perinatology, 42 (1): pp. 61-75. ISSN/28761, 2015.

10- COOLS P.: Vaginal colonization by Group B Streptococcus in different populations of African women: Risk factors and relation with the vaginal microbiome and the cervicovaginal immune system; 15 (2): 35-60. DOI: 10.2546/ JFU/32568, 2017.

11- MACHADO A., CASTRO J., CEREIJA T., ALMEIDA C. and CERCA N.: Diagnosis of bacterial vaginosis by a new multiplex peptide nucleic acid fluorescence in situ hybridization method. Peer. J., 3: e 780, 2015.

12- LANGER O.: Obesity 23 the Times? in Pregnancy: A Sign of. The Diabetes in Pregnancy Dilemma: Leading Change with Proven Solutions, 2e, 257, 2015.

13- WHO (World Health Organization): WHO recommendations on antenatal care for a positive pregnancy experiencegoing beyond survival. DOI: 10.1111/1471-0528.14599, 2017.

14- IBRAHIM Z.M., ABD EL-HAMID S., MIKHAIL H. and KHATTAB M.S.: Assessment of Adherence to Iron and Folic Acid Supplementation and Prevalence of Anemia in Pregnant Women. Med. J. Cairo Univ., 79 (2): 115-21, 2011.

15-ABU SALEM E. MAHMOUD, OMIYMA A. MAHROUS, HEWAIDA M. EL SHAZLY, REDA A. IBRAHEM and SAMAR H.A. AL-OSHARI: Epidemiology of irondeficiency anemia among pregnant women in Menoufia Governorate, Egypt and Taiz Governorate, Yemen: Acomparative study; 4 (29) 1005-1011, DOI: 10.4103/11102098.202491, 2016.

16- CAROLYNE WANJIRU NDUHIU-GITHINJI: Prevalence of anemia among attending antenatal clinic at Mbagathi District Hospital, 30-37, H58/63824/10, 2012.

17- CUNEYT TANER, ATALAY EKIN, ULAS SOLMAZ, GENK GEZER, BIRGUL CETIN, MUSTAFA KELESOGLU, MERVE ERPALA and MEHMET OZEREN Prevelence and risk factor of anemia among pregnant women attending ahigh volume tertiary care center for delivery, 232-4, DOI:10.5152/jtgga.2015.15071, 2015.

18- BARTHÉLÉMY TANDU-UMBA* and ANDY MUELA MBANGAMA: Association of maternal anemia with other risk factors in occurrence of Great obstetrical syndromes 
at university clinics, Kinshasa, Dr congo, 15-183 Doi 10.1186/s12884-015-0623-z, 2015.

19- MISME H., DUPONT C., CORTET M., RUDIGOZ R.C. and HUISSOUD C.: Distribution of blood loss during vaginal delivery and cesarean section. J. Gynecol. Obstet. Biol. Reprod (Paris). 45 (1): 71-9. doi: 10.1016/ j.jgyn.01.004, 2016.

20- NORA A. KHALIL, WALEED M. FATHY and NARIMAN S. MAHMOUD: Screening for Gestational Diabetes Among Pregnant Women Attending a Rural Family Health CenterMenoufia Governorate-Egypt. Journal of Family Medicine and Health Care. Vol. 3, No. 1, pp. 6-11. doi: 2017.

21- KELLY J. HUNT and KELLY L. SCHULLER: The increasing prevalence of diabetes in pregnancy, 34 (2): 173-vii, 2007.

22- JUNHONG LENG, PING SHAO, ZHANG C., TIAN H., ZHANG F., ZHANG S., DONG L., LI L., YU Z., CHAN J.C.N., HU G. and YANG G.: Prevalence of gestational biabetes mellitus and its risk factors in Chinese pregnant women: Aprospective population-based study in Tianjin, China; Doi: 10.1371/journal.pone.0121029, 2015.

23- ERHABOR O., KABIRU SALISU ADAMU, YAKUBU A., SHEHU C.E., HASSAN M. and SINGH S.: Rh (D) Phenotype among Pregnant Women in Sokoto, North Western Nigeria. Implications on Haemolytic Disease of the New-Born and Haemolytic Transfusion Reaction. Vol. 1, No. 2, PP. 19-24, health science research, 2014.

24- IDOWU O.A., MAFIANA C.F. and SOTILOYE DAPO: Rhesus negative pregnant women in a traditional birth home in Abeokuta, Nigeria. Vol. 2 (8): PP. 241-3. ISSN 1684-5315, 2003

25- MEGBARU ALEMU, GUESH ABRHA, GESSESSEW BUGSSA and KIROS TEDLA: Frequency of ABO and Rh (D) Blood Groups and Hemoglobin Threshold amongPregnant Women in Family Guidance Association, Mekelle Model Clinic, North Ethiopia. Vol. 5 No. 12, 8925. ISSN: 0975-9492, 2014.

26- AHMED EL-NAWAWY, ASHRAF T. SOLIMAN, OMAR EL AZZOUNI, EL-SAYED AMER, MOHAMMED AB DEL KARIM, SOHEIR DEMIAN and MONA EL SAYED: Maternal and Neonatal Prevalence of Toxoplasma and Cytomegalovirus (CMV) Antibodies and HepatitisB Antigens in an Egyptian Rural Area, Journal of Tropical Pediatrics Vol. 42, 154-7, 1996.

27- ABDULBASET M. ABUSETTA, GAMAL and ADEL M. SHOBAR: Incidence of Cytomegalovirus Infection among Pregnant Women at Alkhoms City, International Journal of Advanced Research (2013), Volume 1, Issue 9, 345-57; ISSN 2320-5407, 2013.

28- CANNON M.J., SCHMID D.S. and HYE T.B.: Review of cytomegalovirus seroprevalence and demographic characteristics associated with infection, 20 (4): 202-13 Rev. Med. Virol., 2010.

29- SERRA F.C., MACHADO J., NICOLA M.H., et al.: Soroprevalência de citomegalovírus em gestantes brasileiras de classe socioeconômica favorecida. J. Bras Doenças Sex Transm., 21 (1): 12-5, 2009.

30- MAHMOUD EL SAYED ABO-SALEMA, OMAYMA ABO-ELFATEH MAHROUSA, AHMED, AHMED ELSHAARAWYB, HALA MARAWAN MOHAMEDA and SANIA ALI SOLIMAN YEHIA: Seroprevalence of hep- atitis B among pregnant womenattending maternal and child health centres in Shebin El-Kom district (Menoufia governorate), 27: 847-52. IP: 196.133.15.122, 2014

31- YOUSSEF M.A., ABD-ELALEEM H.A. and ELKABSH M.Y.: Prevalence of hepatitis $C$ and hepatitisB among pregnant women in Assiut. Proceedings of Egyptian medical syndicate (EMS) annual sceintific congress, February 2-4, Cairo, Egypt; 1993.

32- ZAHRAN K.M., BADARY M.S., AGBAN M.N. and ABDEL AZIZ N.H.: Pattern of hepatitis virus infection among pregnant women and their newborns at the Women's Health Center of Assiut University, Upper Egypt, 111: 171-4. Int. J. Gynaecol. Obstet., 2010.

33- MORTADA EL-SHABRAWI, MOHAMED FAROUK MOHAMED, MONA SALAH EL DIN HAMDI MOHAMED EHAB, SHAIMAA SHAABAN KHAMISS and HANAA EL-KARAKSY: Prevalence of Hepatitis B Virus Infection among Egyptian Pregnant Women-A Single Center Study. International Journal of TROPICAL DISEASE \& Health, 3 (2): 157-68, 2013.

34- ABDULQAWI K., YOUSSEF A., METWALLY M.A., RAGIH I., ABDULHAMID M. and SHAHEEN ABDULAZIZ: Prospective study of prevalence and risk factors for hepatitis $\mathrm{C}$ in pregnant Egyptian women and its transmission to their infants, 51: 219-28. Doi. 10.3325/ cmj.2010.51.219, 2010.

35- MOHAMOUD Y.A., MUMTAZ G., RIOME S. and ABURADDAD L.J.: The epidemiology of hepatitis $C$ virus in Egypt: A systemic review and data synthesis; 13 (1) 288 Doi: 10.1186/1471-2334-13-288, 2013.

36- KHAMIS H.H., FARGHALY A.G., SHATAT H.Z. and EL-SHITANY E.M.: Prevalence of hepatitis C virus infection among pregnant women in arural district in Egypt, 46 (1): 21-7, Doi: 10. 117710049475514561330, 2014.

37- EDESSY M., AL-DARWISH A.G., EL-KATATNY H.H., ABD EL ATY M.G., ABD EL HAMED, NASR A.A.M. and ABD EL AZEEM O.: Hepatitis $C$ virus infection during pregnancy in Upper Egypt, 2 (10): 8-15. ISSN: 2454-5716, 2016

38- EDESSY M., NASR A.A.M., OUN A. and EL-SAID Y.: Hepatitis $C$ virus infection during pregnancy in Delta Egypt; 2 (4) 83-91. Egypt. J. Adv. Res. Bio. Sci., ISSN: 2348-8069, 2015

39- STEPHEN BERGER: Gideon, Bacterial vaginosis, Global status; 5-35; ISBN: 978-1-4988-1525-3, 2017.

40- IBRAHIM S.M., BUKAR M., GALADIMA G.M., AUDU B.M. and IBRAHIM H.A.: Prevalence of bacterial vaginosis in pregnant women in Maiduguri, North-Eastern Nigeria.; 17 (2): 154-8. Niger. J. Clin. Pract., 2014.

41- SHAHEEN H.M., TAGHREED M. FARAHAT and NESREEN A. EL-HAKEEM HAMMAD: Prevalence of urinary tract infection among pregnant women and possible risk factors, Menoufia Medical Journal, (4) 29: 1055-9; DOI: 10.4103/1110-2098.202505, 2017.

42- BADR A.F.K.: Bacteruria in Egyptian Pregnant Women: A clinical and bacteriological study; 82: 3-4. J. Egypt Public Health Assoc., 2007.

43- SHEIKH M.A., KHAN M.S., KHATOON A., ARAIN G.M.: Incidence of urinary tract infection during pregnancy. East Mediterr Health J., 6: 265-71, 2000. 


\section{الفحوصات التقليدية فى الزيارة التسجيلية لمتابعة الحمل: دراسة مسحية الزية}

"الرعاية قبل الولادة" تشمل التعليم والإرشاد والفحص والعلاج لرصد وتعزيز رفاهية الآم والجنين. الهدف من هذه الدراسة المقطعية هو تصديد الطابع الطبى للنساء الصوامل بكفر الثيخ بناء على نتائج الزيارة الآلى لمتابعة الصمل. طلب من جميع النساء الحوامل إجراء التحاليل المعملية التالية لرعاية ما قبّل الولادة:

$$
\begin{aligned}
& \text { 1- صودة دم كاملة. } \\
& \text { r- قياس سكر عشوائى بالدم. } \\
& \text { r- فصيلة الدم وعامل (ريساس). } \\
& \text { ع- تحليل بول. } \\
& \text { 0- فيروس إلتهاب الكبد ب. } \\
& \text { T- فيروس إلتهاب الكبد ج. } \\
& \text { - فيروس مضخم اللخلايا (CMV) - V }
\end{aligned}
$$

^- مسحة من الإفرازات المهبلية لتشخيص داء المهبل الجرثقيى.

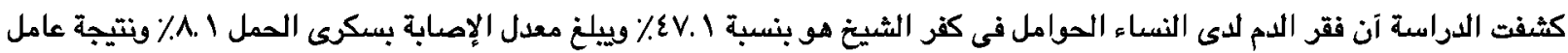

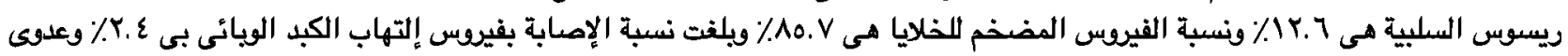

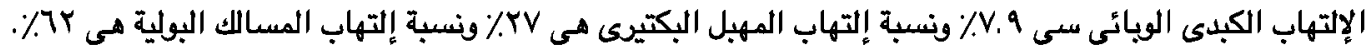
يوصى بإعطاء إهتمام آكبر للرعاية والفحصصات الروتينية لما قبل الولادة. 